\title{
An overview of cold start emissions from direct injection spark-ignition and compression ignition engines of light duty vehicles at low ambient temperatures
}

\begin{abstract}
Spark-ignition (SI) engines are highly susceptible to excess emissions when started at low ambient temperatures, a phenomenon which has been widely discussed in the literature. Direct injection diesel engines feature a markedly different fuelling and combustion strategy, and as such their emissions behaviour is somewhat different from gasoline engines. The excess emissions of diesel engines at low ambient temperatures should also differ. The aim of this study was to compare excess emissions of gaseous and solid pollutants over a legislative driving cycle (the New European Driving Cycle, NEDC) following cold start at a low ambient temperature for both engine types. This paper examines emissions at low ambient temperatures with a special focus on cold start; emissions are also compared to start-up at a higher ambient temperature $\left(24^{\circ} \mathrm{C}\right)$. The causes of excess emissions and fuel consumption are briefly discussed. A series of tests were performed on European Euro 5 passenger cars on a chassis dynamometer within an advanced climate-controlled test laboratory at BOSMAL Automotive Research and Development Institute, Poland. Emissions data obtained over the Urban Driving Cycle by testing at $24^{\circ} \mathrm{C}$ and at $-7{ }^{\circ} \mathrm{C}$, are presented for a selection of modern Euro 5 gasoline and diesel vehicles representative of the European passenger car fleet. A full modal emissions analysis was also conducted at $24^{\circ} \mathrm{C}$ and at $-7{ }^{\circ} \mathrm{C}$ over the NEDC. Emissions and fuel consumption were substantially higher at $-7{ }^{\circ} \mathrm{C}$ than at $24^{\circ} \mathrm{C}$.
\end{abstract}

Keywords: spark ignition (SI) and compression ignition (CI) direct injection engine, cold start, low ambient temperature, excess emissions, emissions deterioration

\section{Emisja związków szkodliwych spalin w czasie rozruchu silnika w niskich temperaturach otoczenia z samochodowych silników o zapłonie iskrowym i samoczynnym}

\begin{abstract}
Celem niniejszej pracy była analiza problemu podwyższonej emisji związków szkodliwych spalin przy eksploatacji samochodów osobowych w niskich temperaturach otoczenia i porównanie emisji gazowych zwiąków szkodliwych spalin $i$ czastek statych z samochodów osobowych spetniajacych wymagania Euro 5 w czasie homologacyjnego testu jezdnego NEDC, rozpoczynającego się od rozruchu zimnego silnika, wykonywanego w normalnych i niskich temperaturach otoczenia. Przeprowadzono analizę wyników badań, uzyskanych w laboratorium emisji spalin Instytutu Badań i Rozwoju Motoryzacji BOSMAL, $w$ zakresie emisji związów szkodliwych spalin $w$ testach prowadzonych $w$ temperaturach otoczenia $+24^{\circ} \mathrm{C} i-7^{\circ} \mathrm{C}$, dla nowoczesnych samochodów napędzanych silniami ZI i ZS, spetniajacych wymagania Euro 5. Stwierdzono znacznie podwyższony poziom emisji związów szkodliwych i zużycia paliwa $w$ testach wykonywanych $w$ ujemnych temperaturach otoczenia. Przyczyny podwyższonej emisji i zużycia paliwa $w$ czasie rozruchu zimnego silnika $i w$ czasie jego eksploatacji w niskich temperaturach otoczenia zostaty przeanalizowane $i$ opisane.

Słowa kluczowe: silniki samochodowe ZI I ZS, rozruch zimnego silnika, niskie temperatury otoczenia, podwyższona emisja zwiąków szkodliwych
\end{abstract}

\section{Introduction}

Cold start emissions behaviour represents perhaps the greatest single issue for emissions control regarding passenger cars [1-3], and a key theme for the development of affective aftertreatment systems. Before an engine of any type can perform useful work, it must be started. In the case of passenger cars, each journey (or segment of a journey) necessitates a start-up event. For successful start-up, and acceptable drivability immediately thereafter, fuel enrichment (use of a 'rich' fuel-air mixture) is necessary, particularly for spark-ignition engines. Additionally, catalyst light-off is delayed at lower ambient temperatures and $\mathrm{CO}$ and $\mathrm{HC}$ are not oxidized in this system during the period immediately following start-up. The results of this is that start-up events are significant in terms of emissions and fuel consumption, with a strong dependency on the temperature of the engine and the temperature of the ambient air.

Start-up events are the most fundamental transient events experienced by automotive engines as the numerical values of engine speed and fuel consumption change from zero to non-zero values in a very short space of time, even before any power is transferred to the wheels [3]. Both hot and cold start events can be classified as transient operation of an internal combustion engine [3]. Cold start can be defined as when an engine is started with the temperatures of the oil, coolant and all elements of the engine ( $\mathrm{T}$ ) at the ambient temperature $\left(T_{a}\right)[3]$. During hot start, the temperature of all these elements will be very close to those observed during fully warmed-up operation $\left(\mathrm{T}_{\mathrm{w}}\right)$. The term 'cool start' can be used to refer to intermediate temperatures (i.e. $\mathrm{T}_{\mathrm{a}}<\mathrm{T}<\mathrm{T}_{\mathrm{w}}$ ) [3]. Cool and cold starts represent a significant challenge in 


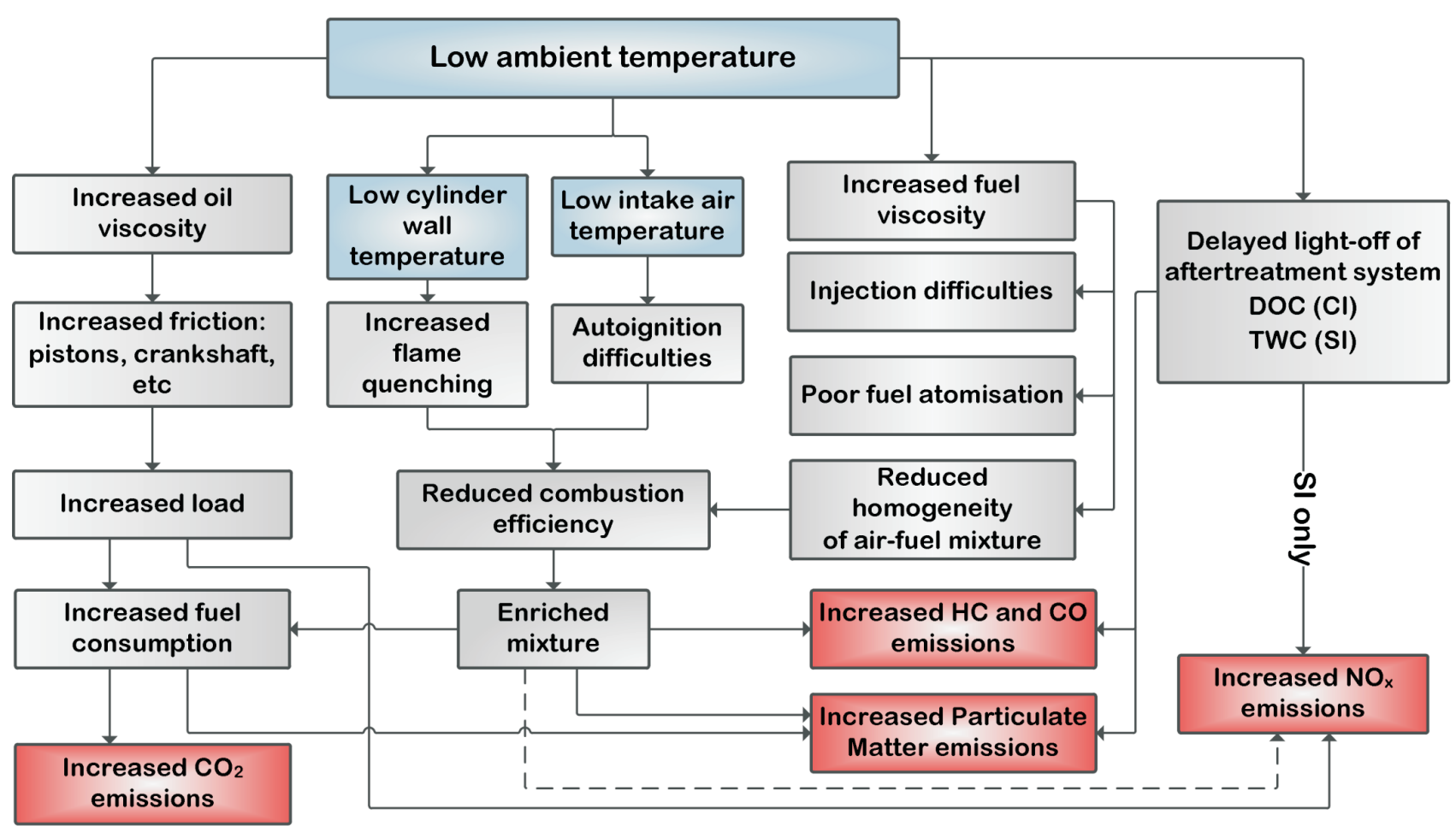

Fig. 1. Cause-and-effect diagram of the fundamental difficulties of cold-start operation at low ambient temperatures for SI and CI engines

terms of forming combustible mixtures while maintaining exhaust emissions and fuel consumption at reasonable levels, and this problem becomes progressively worse with reducing ambient temperatures. Emissions of regulated exhaust gas components, carbon dioxide $\left(\mathrm{CO}_{2}\right)$ and fuel consumption (FC) all generally show measurable differences with varying $T_{a}[1-9]$.

The effect of low and sub-zero ambient temperatures on cold starts of internal combustion engines fitted to passenger cars has been widely reported and discussed in the literature [1-9]. The temperature range used globally for type-approval testing is typically $20^{\circ} \mathrm{C}$ to $30^{\circ} \mathrm{C}$, but colder conditions a few degrees above zero cause greater emissions and fuel consumption and this trend continues as ambient temperatures fall below zero degrees Celsius. While the mathematical form of the response is variable [3], low ambient temperature cold starts lead to higher emissions of hydrocarbons (HC), carbon monoxide $(\mathrm{CO})$, and carbon dioxide $\left(\mathrm{CO}_{2}\right)$. Fuel consumption is greater and emission of oxides of nitrogen $\left(\mathrm{NO}_{\mathrm{x}}\right)$ can also be increased. Aftertreatment systems do not function properly during the first 20-100 seconds of engine operation following cold start, having not yet reached lightoff, and this prevents effective mitigation of the increased tailpipe emissions of $\mathrm{HC}, \mathrm{CO}$ and $\mathrm{NO}_{\mathrm{x}}$.

\section{Legislative emissions limits and testing of cold ambient emissions}

Starting in the early 1990s, interest began to grow in cold start events and the attendant emissions and a number of studies and analyses were published. Various regulatory authorities have mandated emissions limits for testing of passenger cars at ambient temperatures below the standard $20{ }^{\circ} \mathrm{C}-30{ }^{\circ} \mathrm{C}$ range. These procedures and limits are summarised in Table 1. Low temperature test and emissions limits were introduced for the first time in the USA's Code of Federal Regulation (CFR) legislation. Following analyses of automotive cold start emissions behaviour in the 1990s, testing at low ambient temperatures was introduced in 1994 in the USA from MY 94 (Tier I) vehicles, with an limit to control CO emissions (10 grams/mile over the FTP 75 test cycle) at low ambient temperatures; the cold $\mathrm{CO}$ limit must be met at all altitudes. The state of California developed its own test procedure; all non-diesel vehicles from $96 \mathrm{MY}$ onwards also need to meet a cold CO limit, an additional

Table 1. EU and US/EPA-CARB legislation trends of cold ambient emissions

\begin{tabular}{|l|c|c|c|c|c|}
\hline Legislation & Temp. & Cycle & $\begin{array}{c}\mathrm{HC} \\
{[\mathrm{g} / \mathrm{km}]}\end{array}$ & $\begin{array}{c}\mathrm{CO} \\
{[\mathrm{g} / \mathrm{km}]}\end{array}$ & $\begin{array}{c}\mathrm{NO}_{\mathrm{x}} \\
{[\mathrm{g} / \mathrm{km}]}\end{array}$ \\
\hline $\begin{array}{l}\text { EU/SI vehicles } \\
\text { (Euro 5) }\end{array}$ & $-7^{\circ} \mathrm{C}$ & UDC & Yes & Yes & No \\
\hline $\begin{array}{l}\text { EU/CI vehicles } \\
\text { (Euro 5) }\end{array}$ & None & None & No & No & No \\
\hline $\begin{array}{l}\text { EU/CI vehicles } \\
\text { (Euro 6) }\end{array}$ & $-7^{\circ} \mathrm{C}$ & UDC & No & No & Yes? \\
\hline $\begin{array}{l}\text { EU/CI vehicles } \\
\text { (Euro 7?) }\end{array}$ & $\begin{array}{c}10^{\circ} \mathrm{C} ? \\
-7^{\circ} \mathrm{C} ?\end{array}$ & $\begin{array}{l}\text { NEDC? } \\
\text { WLTC? }\end{array}$ & Yes? & Yes? & Yes? \\
\hline USA/EPA & $-6.7^{\circ} \mathrm{C}$ & FTP-75 & No & Yes & No \\
\hline $\begin{array}{l}\text { California/ } \\
\text { CARB }\end{array}$ & $10^{\circ} \mathrm{C}$ & $\begin{array}{c}\text { Unified } \\
\text { Cycle }\end{array}$ & Yes & Yes & Yes \\
\hline $\begin{array}{l}\text { California/ } \\
\text { CARB }\end{array}$ & $-7^{\circ} \mathrm{C}$ & $\begin{array}{c}\text { Unified } \\
\text { Cycle }\end{array}$ & No & Yes & No \\
\hline USA (Future) & $-6.7^{\circ} \mathrm{C} ?$ & $?$ & No? & Yes & Yes? \\
\hline
\end{tabular}


test performed at $10^{\circ} \mathrm{C}$ with limits for $\mathrm{HC}, \mathrm{CO}$ and $\mathrm{NO}_{\mathrm{x}}$ was introduced. Following these changes, in 2000 the European Union firstly adapted the Euro 3 test procedure to synchronise sampling of the exhaust gas with the start of cranking (thereby eliminating the 40 second warm-up period which had existed previously). This change effectively forced manufacturers to mount catalytic aftertreatment systems in the close-coupled configuration (CCC), in order to minimise light-off time and ensure effective mitigation of the $\mathrm{HC}$ and $\mathrm{CO}$ emissions associated with start-up. Furthermore, the EU introduced a test at $-7{ }^{\circ} \mathrm{C}$ for all $\mathrm{SI}$ vehicles from 2002 onwards. Measurement is performed over the first part of the NEDC cycle - the UDC (780 seconds), with set limits for emission of $\mathrm{HC}$ and $\mathrm{CO}$. The Euro 5 regulations introduced additional requirements for SI flex-fuel vehicles, where measurement must be performed on two fuel types: gasoline and E75 (Euro 5b). An planned additional requirement is now in place for type-approval testing of $\mathrm{CI}$ vehicles, which requires that the $\mathrm{NO}_{\mathrm{x}}$ aftertreatment device reaches "a sufficiently high temperature for efficient operation" within 400 seconds following cold start at $-7^{\circ} \mathrm{C}[10]$.

\section{Analysis of sample test results}

All sample results presented here were obtained during the course of work carried out in the Euro 5/6-compliant vehicle emissions testing laboratory at BOSMAL Automotive R\&D Institute (Poland) over the years 2010-2013 within a test programme investigating cold start effects at low ambient temperature conditions on the emissions from light duty vehicles fuelled with standard fuels as well as alternative fuels. Further information about this programme can be found in the authors' papers on those subjects [3-5]. The aforementioned laboratory is housed within a climatic chamber capable of creating stable temperatures within the range $-35^{\circ} \mathrm{C}$ to $+60^{\circ} \mathrm{C}$ (see $[11,12]$ and Appendix 1 for a detailed description of this test facility). Vehicles were tested on a chassis dynamometer located within this climatic chamber (Fig. 2).

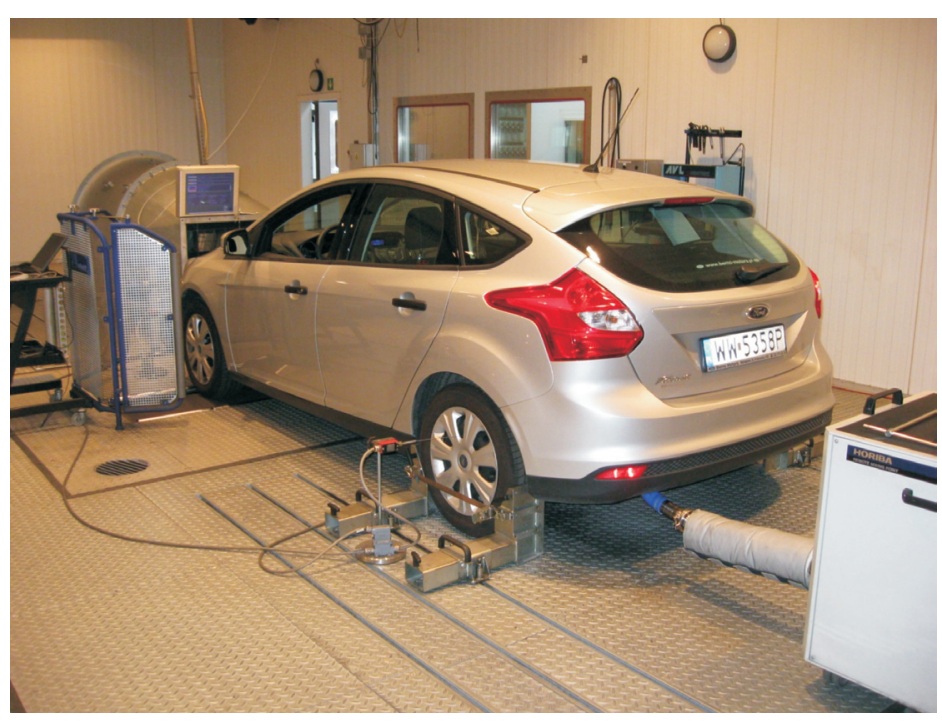

Fig. 2. Exhaust emissions laboratory at BOSMAL Automotive R\&D Institute, showing the chassis dynamometer, windspeed fan and a vehicle, all within the climatic chamber
Over the aforementioned timeframe, many different experiments were performed. In one such experiment, the EU Urban Driving Cycle (UDC) was used to test a pool of MPI test vehicles at $-7{ }^{\circ} \mathrm{C}$, according to EU legislative requirements [10]. Using a constant volume sampler, diluted exhaust gas was collected in emissions sampling bags for analysis of $\mathrm{HC}$ and $\mathrm{CO}$ emissions; $\mathrm{CO}_{2}$ emissions were also measured. In a further two experiments, an MPI vehicle and a DISI vehicle with approximately equal cylinder displacement and comparable unladen mass were tested over the NEDC at ambient temperatures of $-7{ }^{\circ} \mathrm{C}$ and $+24^{\circ} \mathrm{C}$. For both vehicles, $\mathrm{HC}, \mathrm{CO}, \mathrm{NO}_{x}$ and $\mathrm{CO}_{2}$ were also measured. For the DISI vehicle, particulate matter (PM) emissions were quantified using gravimetric and condensation particle counter methods, according to the relevant EU legislation.

The non-dimensional emission factors $\mathrm{HC}, \mathrm{CO}, \mathrm{NO}_{\mathrm{x}}$, and

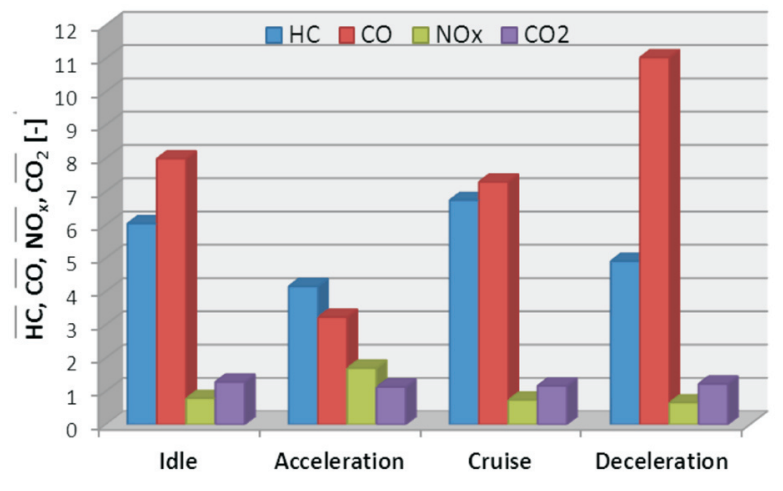

Fig. 3. A modal analysis of excess emissions from a SI LDV tested over the NEDC at $-7{ }^{\circ} \mathrm{C}$ in comparison to $24{ }^{\circ} \mathrm{C}$

$\mathrm{CO}_{2}$ are calculated by dividing the modal emission factor from the test conducted at $-7^{\circ} \mathrm{C}$ by the equivalent emission factor from the test conducted on the same vehicle at $24^{\circ} \mathrm{C}$. Where the value generated was greater than 0 but less than 1 , the emissions were found to take lower (but nonzero) values at $-7{ }^{\circ} \mathrm{C}$; values greater than 1 indicate increased emissions at the lower test temperature. The SI vehicle showed substantial excess emissions of HC and CO over the NEDC cycle following a cold start at $-7{ }^{\circ} \mathrm{C}$ (Fig. 3). $\mathrm{NO}_{x}$ emissions were generally lower than at $24{ }^{\circ} \mathrm{C}$, and $\mathrm{CO}_{2}$ emissions were somewhat higher, reflecting an increased fuelling rate. The ratio of $\mathrm{HC}$ to $\mathrm{CO}$ was found to be highly variable. $\mathrm{CO}$ emissions were notably higher during decelerations, while $\mathrm{HC}$ emissions did not show an increase of the same magnitude. $\mathrm{HC}$ and $\mathrm{CO}$ emissions occurring during fuel cut-off suggests that appreciable quantities of fuel had accumulated on the cylinder surfaces, which were then later released. It was noted that $\mathrm{HC}$ was slightly higher during cruise than during idle; the reason for this unexpected result is not clear at this time.

$\mathrm{NO}_{\mathrm{x}}$ emissions were reduced during all modes other than acceleration, strongly suggesting lower 


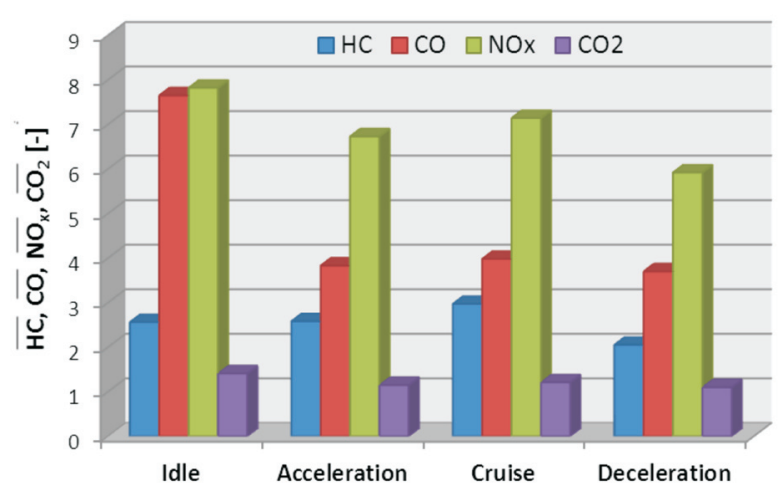

Fig. 4. A modal analysis of excess emissions from a CI LDV tested over the NEDC at $-7^{\circ} \mathrm{C}$ in comparison to $24^{\circ} \mathrm{C}$

overall engine temperatures. However, where the mixture is extra enriched, to overcome greater friction and accelerate the vehicle, $\mathrm{NO}_{\mathrm{x}}$ formation was some 70 per cent higher than at $24{ }^{\circ} \mathrm{C}$. The extra-rich mixture probably gave rise to higher peak temperatures and pressures and starved the catalyst of oxygen, all of which increased $\mathrm{NO}_{\mathrm{x}}$ production. The smooth, gradual accelerations of the NEDC may underestimate $\mathrm{NO}_{x}$; real-world excess emissions could be much greater. Excess $\mathrm{CO}_{2}$ emissions varied relatively little from mode to mode. The value for idle is partially due to the higher proportion of idling early in the NEDC (when frictional losses are greatest); the value for deceleration may be a result of the fact that the three-way catalyst manages to oxidize some of the excess $\mathrm{CO}$ and $\mathrm{HC}$ to $\mathrm{CO}_{2}$.

In marked contrast to the SI vehicle, the diesel passenger car showed large excess $\mathrm{NO}_{\mathrm{x}}$ emissions during all modes (Fig. 4). $\mathrm{CO}$ was also problematic, and $\mathrm{HC}$ were less so (Fig. 4). The massive increase in $\mathrm{NO}_{\mathrm{x}}$ is unlikely to be due to temperature increases alone, as experimental data show that $\mathrm{CI}$ engine-out temperatures are broadly similar irrespective of whether Ta is $24^{\circ} \mathrm{C}$ or $-7^{\circ} \mathrm{C}$ (see [3] and references therein). The excess $\mathrm{NO}_{x}$ production was probably a result of the antagonism between slightly higher combustion temperatures and poor mixing of the air and fuel. Both these effects can be explained by a single factor, namely the use of a highly enriched mixture. The high value of $\mathrm{CO}_{2}$ for idle is probably

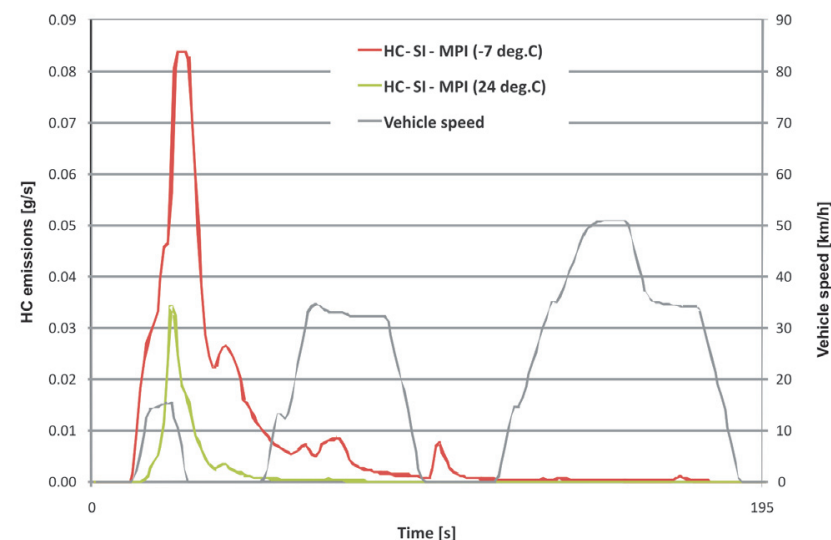

Fig. 5. Second-by-second $\mathrm{HC}$ emission results from an SI vehicle, over the first 195 seconds of the UDC, when tested at $-7{ }^{\circ} \mathrm{C}$ and at $24^{\circ} \mathrm{C}$ due to early phases of the cycle where the lubricant showed a high viscosity.

The first segment of the UDC (0-195 seconds) is of considerable interest regarding $\mathrm{HC}$ and $\mathrm{CO}$ emissions. During this period, the engine firstly undergoes a cold start, then begins to transfer power to the wheels and accelerate, and then TWC light-off typically occurs soon after. Modal emissions results for $\mathrm{HC}$ and $\mathrm{CO}$ during this period are presented in Figs 4 \& 5 .

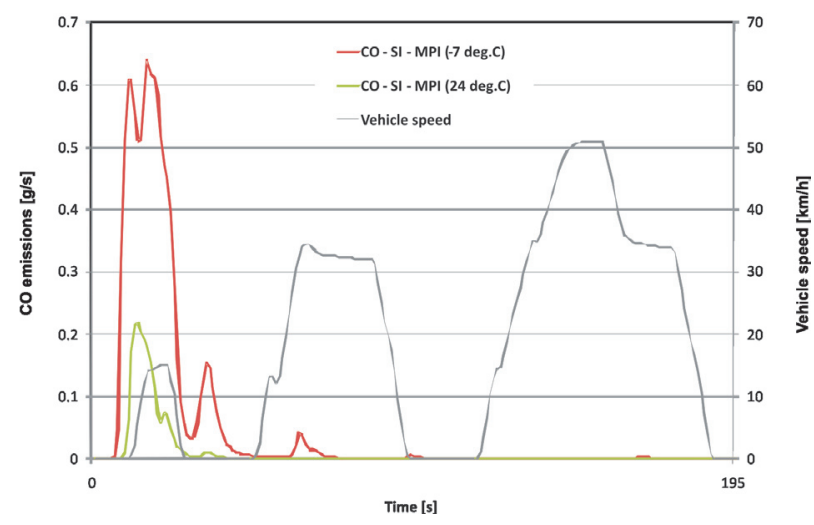

Fig. 6. Second-by-second $\mathrm{CO}$ emission results from an SI vehicle, over the first 195 seconds of the UDC, when tested at $-7^{\circ} \mathrm{C}$ and at $24^{\circ} \mathrm{C}$

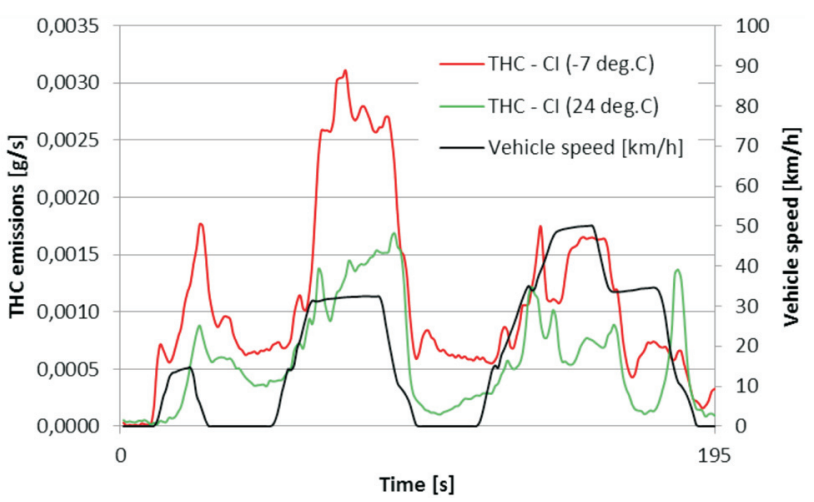

Fig. 7. Second-by-second THC emission results from an $\mathrm{CI}$ vehicle, over the first 195 seconds of the UDC, when tested at $-7{ }^{\circ} \mathrm{C}$ and at $24{ }^{\circ} \mathrm{C}$

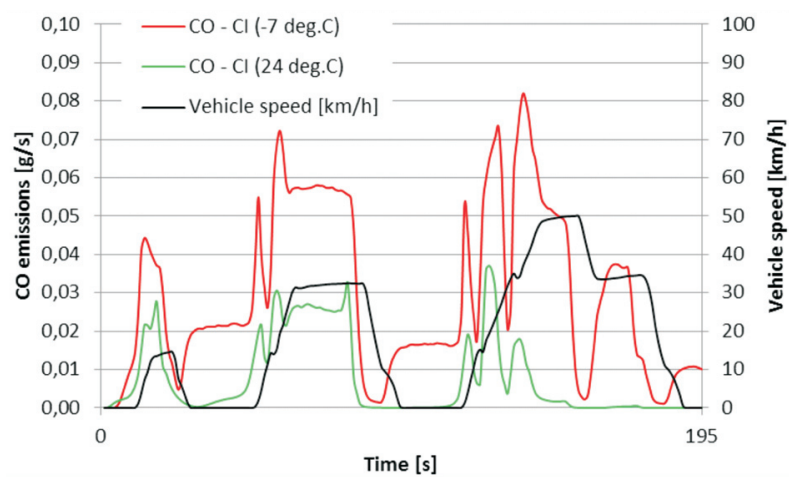

Fig. 8. Second-by-second $\mathrm{CO}$ emission results from an CI vehicle, over the first 195 seconds of the UDC, when tested at $-7{ }^{\circ} \mathrm{C}$ and at $24^{\circ} \mathrm{C}$ 


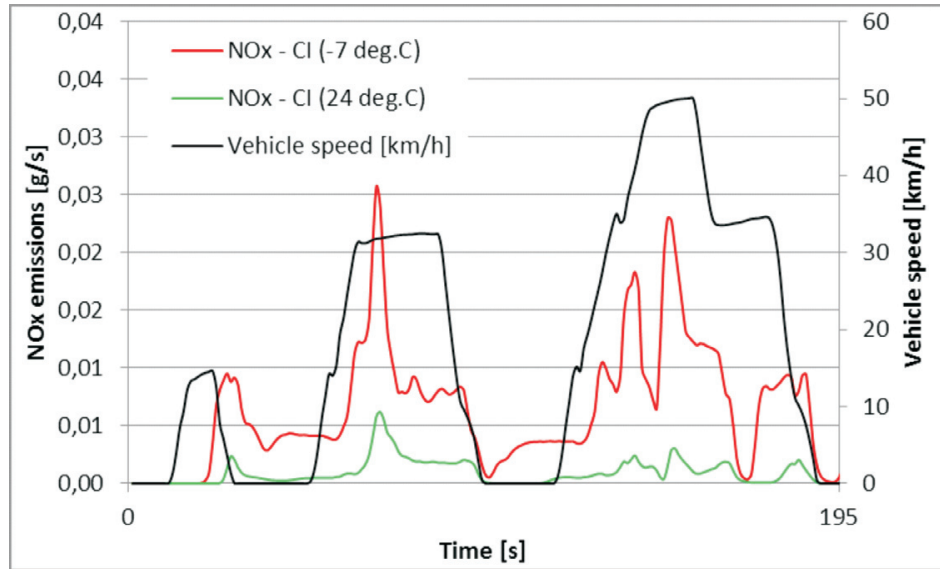

Fig. 9. Second-by-second $\mathrm{NO}_{x}$ emission results from an CI vehicle, over the first 195 seconds of the UDC, when tested at $-7^{\circ} \mathrm{C}$ and at $24^{\circ} \mathrm{C}$

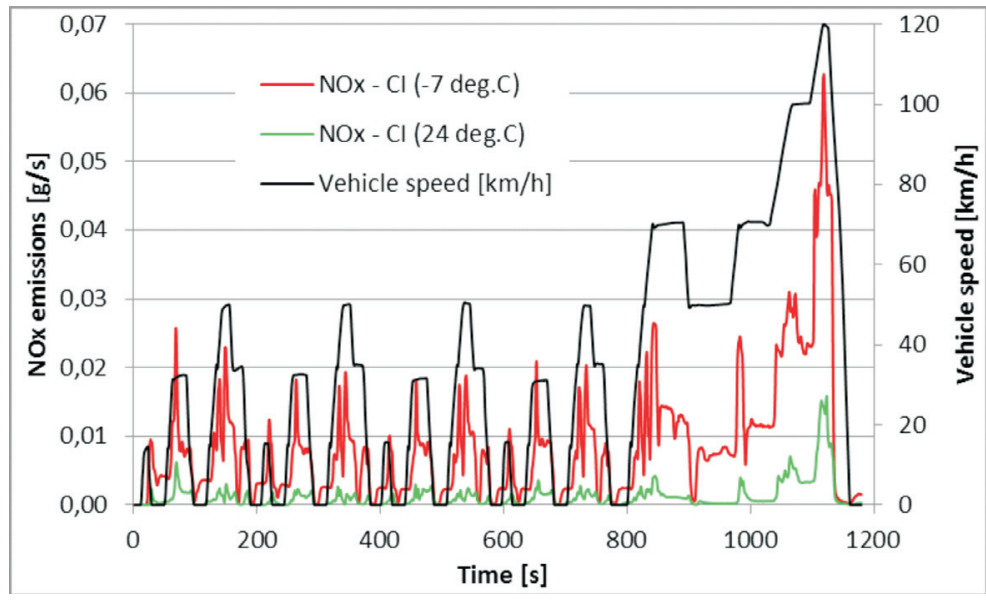

Fig. 10. Second-by-second $\mathrm{NO}_{\mathrm{x}}$ emission results from an CI vehicle, over $1180 \mathrm{sec}-$ onds of the NEDC, when tested at $-7{ }^{\circ} \mathrm{C}$ and at $24{ }^{\circ} \mathrm{C}$

The SI vehicle's HC and CO emissions traces followed a similar trend at both temperatures, but this trend was greatly magnified at $-7{ }^{\circ} \mathrm{C}$. While start-up itself failed to generate substantial emissions, the first ramp, where engine speed rose above idle for the first time, caused a surge in $\mathrm{HC}$ and $\mathrm{CO}$ emission at both temperatures. Emissions thereafter decreased relatively smoothly, despite further periods of acceleration, because the TWC had reached light-off and could deal with $\mathrm{HC}$ and $\mathrm{CO}$ reasonably effectively.

In the case of the diesel engines, the trends are similar, but excess emissions in the first segment of the UDC (0-195 seconds) is of considerable interest not only regarding $\mathrm{HC}$ and $\mathrm{CO}$ but also $\mathrm{NO}_{\mathrm{x}}$ emissions (Figs 7-9). The CI vehicle's $\mathrm{HC}, \mathrm{CO}$ and $\mathrm{NO}_{\mathrm{x}}$ emissions traces followed a similar trend at both temperatures, but this trend was greatly magnified at $-7^{\circ} \mathrm{C}$. Overall, it is possible to state that emissions occurred at the same points in the cycle, but with the low ambient temperature greatly increasing the concentration of the regulated pollutants in the exhaust gas during these periods of emission. Evidently the increased friction and combustion difficulties conspired to cause deteriorations at precisely the same points where emission in usually greatest anyway (when the standard ambient temperature is used). A particularly striking example of this was the case of $\mathrm{NO}_{\mathrm{x}}$ (Fig. 10), where the small emissions fluctuations observed at $24{ }^{\circ} \mathrm{C}$ were also present at $-7^{\circ} \mathrm{C}$, but with a massively increased 'amplitude'.

Low ambient temperature emissions from vehicles are of great interest, as this engine type is becoming more and more widespread. Results comparing $\mathrm{HC}$ and $\mathrm{CO}$ emissions from MPI and DISI vehicle over the UDC at $-7{ }^{\circ} \mathrm{C}$ are shown in Fig. 11. Interestingly, no significant difference was observed in the case of either of the DISI vehicles tested; both vehicles' values lay within the range covered by results for the MPI vehicles, albeit slightly on the low side regarding HC emissions.

A modal emissions analysis performed over the entire NEDC for a DISI vehicle at both test temperatures enabled derterioration factors to be calculated (Fig. 12). Deteriorations were greatest for $\mathrm{HC}, \mathrm{CO}$ and $\mathrm{PM}$; the deteriorations for $\mathrm{CO}_{2}$ and PN were relatively low and were almost identical during the two phases of the cycle. A comparison of these results with results obtained from other vehicles (of different types and ages) is presented in Fig. 13. It is immediately apparent from Fig. 13 that the emissions deterioration over the NEDC varies widely by vehicle type, with particularly interesting results for PM and PN, which require further investigation.

\section{Summary and conclusions}

This study has presented sample results demonstrating that modern vehicles fulfilling the latest, most stringent European emissions standards still suffer serious deteriorations in their ecological performance at low ambient temperatures. Real-world behaviour (outside the laboratory) may be even worse, particularly for $\mathrm{NO}_{\mathrm{x}}$ (see [3] and references therein). High viscosity and friction are the chief primary causes of emissions deterioration; excess fuelling is the chief secondary cause. In light of this, countermeasures such as heating aids and advanced thermal management systems continue to be of interest as options for further improvement of the cold start performance of the CI engine type (see e.g. [3, 8]). Evidence shows that cold start performance has generally improved somewhat in response to the introduction of strict emissions standards [8]. Therefore, the development of the Euro 7 standards (and beyond), alongside the drafting of ever more stringent standards in the USA, will likely exert an impact of cold start emissions behaviour. In the EU, momentum is building towards the introduction of mandatory type-approval testing for light-duty diesel vehicles at low ambient temperature $[3,9]$. Research into the areas of CI cold start emissions and CI emissions behaviour under real-world conditions remain important areas worthy of the 


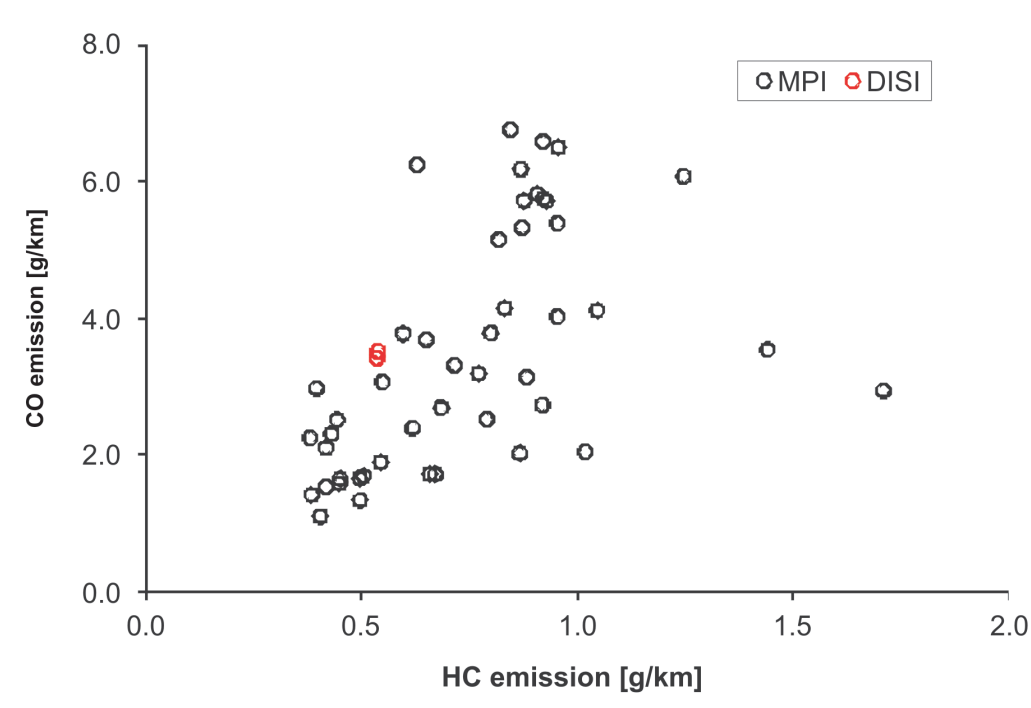

Fig. 11. A scatterplot of $\mathrm{HC}$ and $\mathrm{CO}$ emissions factors for test vehicles, tested over the UDC at $-7^{\circ} \mathrm{C}$

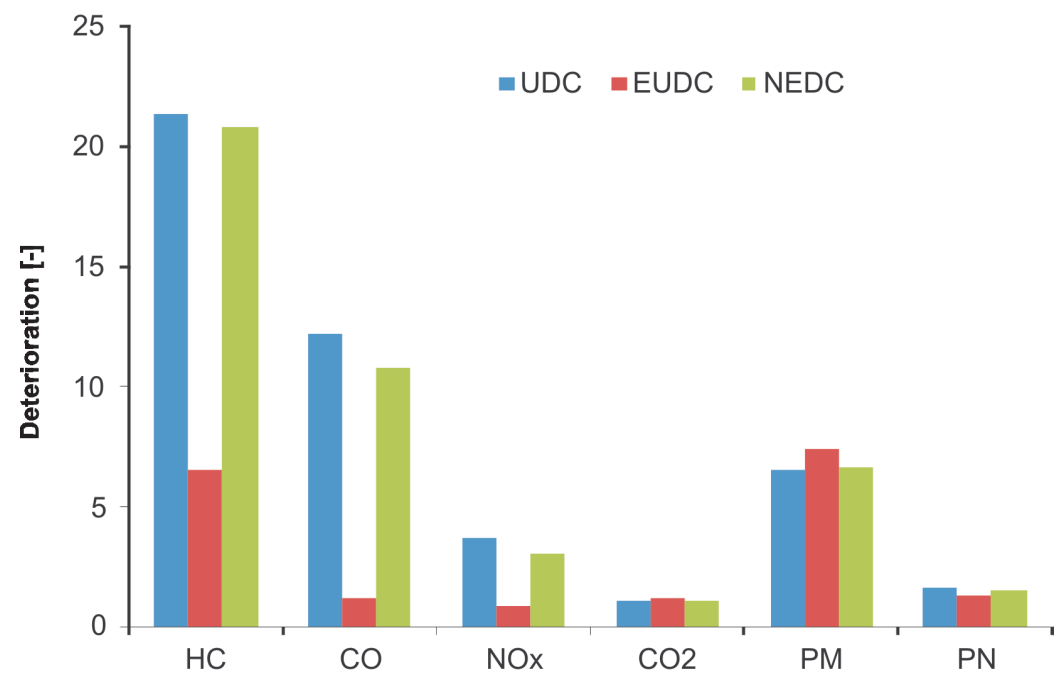

Fig. 12. Deterioration factors for a DISI vehicle tested over the NEDC at $24{ }^{\circ} \mathrm{C}$ and at $-7^{\circ} \mathrm{C}$

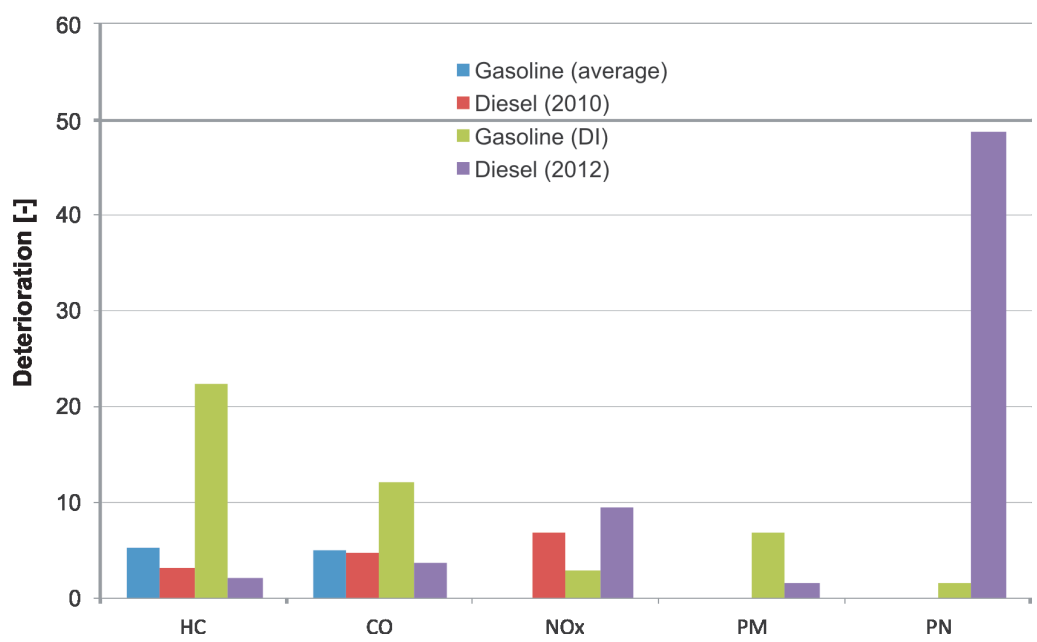

Fig. 13. Emissions deterioration factors over the NEDC for a range of vehicles tested at $23{ }^{\circ} \mathrm{C}$ to $25^{\circ} \mathrm{C}$ and at $-7{ }^{\circ} \mathrm{C}$ attention of engineers and scientists involved in automotive testing.

Automotive emissions regulations should consider adapting the measuring procedures to better reflect real, in-field operating conditions, a major component of which is operation at low ambient temperatures. A good first step in this direction would be to mandate a UDC cycle at $-7{ }^{\circ} \mathrm{C}$ for all vehicles featuring $\mathrm{CI}$ engines, with limits set for emissions of $\mathrm{CO}, \mathrm{HC}+\mathrm{NO}_{x}, \mathrm{PM}$ and $\mathrm{PN}$. For vehicles with DISI engines, limits for PM and PN could be introduced alongside the existing limits. Additionally, $\mathrm{CO}_{2}$ and $\mathrm{FC}$ could also be measured during such as test, and reported alongside results from testing at $20{ }^{\circ} \mathrm{C}$ to $30{ }^{\circ} \mathrm{C}$, in order to provide potential buyers with further information on the cost of ownership of a given vehicle or engine type.

While the fuel consumption penalties (visible in the emissions results; chiefly $\mathrm{CO}_{2}$ ) reported here might not appear to be particularly severe, the substantial fuel consumption penalty observed over the UDC (approaching $30 \%$ ) would have a considerable impact on fuelling requirements where a vehicle was repeatedly used for short (urban) journeys.

In recent years, consumers have begun to demand more realistic fuel consumption statistics and the ubiquity of the internet enables rapid dissemination of informal fuel consumption data obtained by vehicle users - thus, it is in manufacturers' interests to simultaneously optimize engine operation and minimize fuel consumption at a range of ambient temperatures, including the sub-zero temperatures encountered in many areas of Europe, Asia and the Americas.

While regulated and unregulated emissions are of relatively little direct consequence to a vehicle owner/operator (and not easily measured), fuel consumption (and therefore $\mathrm{CO}_{2}$ emissions) are of great concern to the user (and very easily measured). For that reason, it is in manufacturers interest to concentrate their efforts towards the improvement and optimisation of cold start performance of vehicle from both the emissions and fuel consumption points of view, to ensure consumer satisfaction and ensure compliance with existing legislation and certain legislative moves which appear likely for the immediate future, such as the introduction of a low ambient temperature cold start test for diesel vehicles in the EU. 


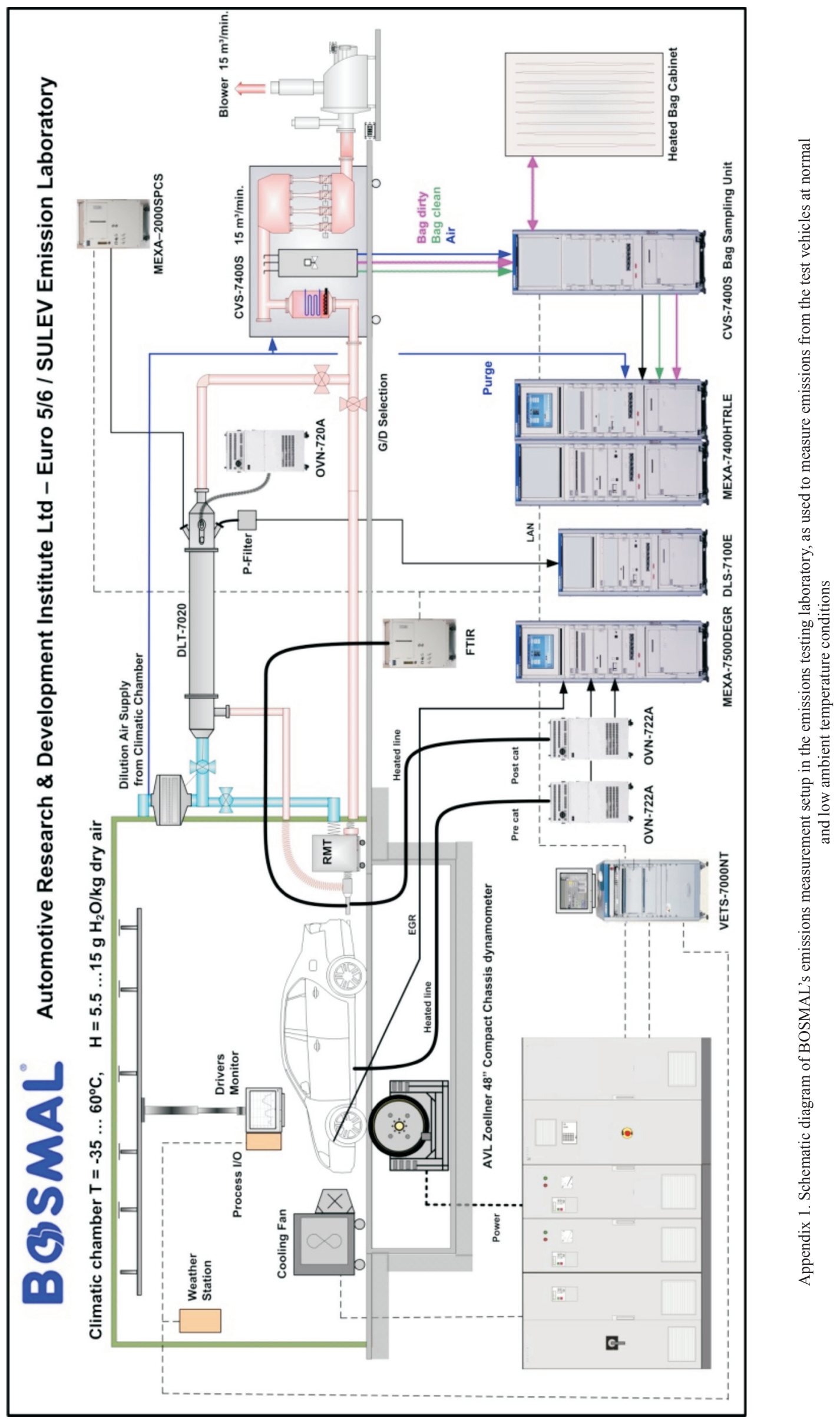




\section{Nomenclature/Skróty i oznaczenia}

$\mathrm{CO}$ carbon monoxide

$\mathrm{CO}_{2}$ carbon dioxide

$\mathrm{CI}^{2}$ compression ignition

CVS constant volume sampler

CARB California Air Resource Board

ECE [United Nations] Economic Commission for Europe

EPA Environmental Protection Agency (USA)

EU European Union

EUDC Extra Urban Driving Cycle

EPA Environmental Protection Agency

HC hydrocarbons

LCV light commercial vehicle

MPI multi-point injection
NEDC New European Driving Cycle

$\mathrm{NO}_{x}$ oxides of nitrogen

$\mathrm{PC}^{\mathrm{x}}$ passenger car

PM particle mass

$\mathrm{PN}$ particle number

SI spark ignition

SUV sport-utility vehicle

$\mathrm{T}$ conceptual mean temperature of the coolant, oil and all engine elements

TWC three-way catalyst

$\mathrm{T}_{\mathrm{a}} \quad$ ambient temperature

$\mathrm{T}_{\mathrm{w}}^{\mathrm{a}}$ temperature of the oil and coolant when the vehicle is fully warmed up

UDC Urban Driving Cycle

WLTC World harmonized light duty vehicle test cycle

\section{Bibliography/Literatura}

[1] Bielaczyc P., Merkisz, J.: Exhaust emission from passenger cars during engine cold start and warm-up. SAE Technical Paper 970740, 1997 SAE World Automotive Congress, Detroit, USA, doi:10.4271/970740.

[2] Bielaczyc P., Merkisz, J., Pielecha, J.: Investigation of exhaust emissions from DI diesel engine during cold and warm start. SAE Technical Paper 2001-01-1260, E: "Progress In Diesel Engine Combustion Processes" SP-1580, 53-60, doi:10.4271/2001-01-1260.

[3] Bielaczyc P., Szczotka A., Woodburn J.: The effect of a low ambient temperature on the cold-start emissions and fuel consumption of passenger cars, Journal of Automobile Engineering, 225, 9, 1253-1264, 2011, doi: 10.1177/0954407011406613.

[4] Bielaczyc P., Szczotka A., Woodburn J.: Excess emissions and fuel consumption of modern spark ignition passenger cars at low ambient temperatures. SAE Technical Paper 2012-011070, 2012, doi: 10.4271/2012-01-1070.

[5] Bielaczyc P., Woodburn J., Szczotka A.: An investigation into cold start emissions from compression ignition engines using EU legislative emissions test procedures. SAE Int. Journal Fuels Lubr. 6(2):2013, doi: 10.4271/2013-01-1304. 2013 SAE World Congress, Detroit, Mi, USA.

[6] Weilennmann M., Favez J.-Y., Alvarez R.: Cold-start emissions of modern passenger cars at different low ambient temperatures and their evolution over vehicle legislation categories, 2009, Atmospheric Environment, 43, 2419-2429. doi: 10.1016/j. atmosenv.2009.02.005.

[7] Dardiotis C., Marotta A., Martini G., Bonnel P., Tutuianu M., Weiss M.: JRC's contribution to the revision of the european type approval procedure for light duty vehicles. Proceedings of the 3rd International Exhaust Emissions Symposium, 24-25 May 2012, Bielsko-Biala, Poland, ISBN 978-83-931383-2-6, Combustion Engines 2(149), 2012.

Piotr Bielaczyc, DEng. - head of the Engine Research Department, BOSMAL Automotive Research and Development Institute Ltd in Bielsko-Biała.

Dr inż. Piotr Bielaczyc - kierownik Zakładu Badań Silników, Instytut Badań i Rozwoju Motoryzacji BOSMAL Sp. z o.o., Bielsko-Biała.

e-mail:piotr.bielaczyc@bosmal.com.pl
[8] Laurikko J.: Cold-start emissions and excess fuel consumption at low ambient temperatures - assessment of EU2, EU3 and EU4 passenger car performances. FISITA paper: F2008-06049, 2008.

[9] Dardiotis C., Martini G., Marotta A., Manfredi U.: Extension of low temperature emission test to Euro 6 diesel vehicles, JRC Report EUR 25408 EN, 2012, doi: 10.2788/37684.

[10] Commission Regulation (EC) No 692/2008 of 18 July 2008 implementing and amending Regulation (EC) No 715/2007 of the European Parliament and of the Council on type-approval of motor vehicles with respect to emissions from light passenger and commercial vehicles (Euro 5 and Euro 6) and on access to vehicle repair and maintenance information, Official Journal of the European Union, L199/1, 2008.

[11] Bielaczyc P., Szczotka A., Woodburn J.: Development of vehicle exhaust emission testing methods - BOSMAL's new emission testing laboratory, Combustion Engines 1(144), 3-12, 2011.

[12] Bielaczyc P., Szczotka A., Pajdowski P., Woodburn J.: Development of automotive emissions testing equipment and test methods in response to legislative, technical and commercial requirements. Combustion Engines 1(152), 2013.

Andrzej Szczotka, DEng. - doctor in Engine Research Department at the BOSMAL Automotive Research \& Development Institute Ltd in Bielsko-Biała.

Dr inż. Andrzej Szczotka-adiunkt w Zakładzie Badań Silników Instytut Badań i Rozwoju Motoryzacji BOSMAL Sp. z o.o., Bielsko-Biała.

e-mail: andrzej.szczotka@bosmal.com.pl

Joseph Woodburn, MSci. - researcher at the Engine Research Department, BOSMAL Automotive Research and Development Institute Ltd in Bielsko-Biała.

Mgr inż. Joseph Woodburn - inżynier ds. badań w Zaktadzie Badań Silników, Instytut Badań i Rozwoju Motoryzacji BOSMAL Sp. z o.o., Bielsko-Biała. e-mail: joseph.woodburn@bosmal.com.pl 